\title{
Trade unionists and the Labour Party in Britain:
} the bedrock of success

Les syndicalistes et le parti travailliste en Grande-Bretagne : le socle du succès

\section{Chris Wrigley}

\section{(2) OpenEdition}

1 Journals

\section{Electronic version}

URL: http://journals.openedition.org/rfcb/1138

DOI: $10.4000 /$ rfcb. 1738

ISSN: 2429-4373

\section{Publisher}

CRECIB - Centre de recherche et d'études en civilisation britannique

\section{Printed version}

Date of publication: 27 July 2009

Number of pages: $59-72$

ISBN: 978-2-9115-8028-4

ISSN: 0248-9015

\section{Electronic reference}

Chris Wrigley, "Trade unionists and the Labour Party in Britain: the bedrock of success », Revue Française de Civilisation Britannique [Online], XV-2 | 2009, Online since 01 November 2016, connection on 10 December 2020. URL : http://journals.openedition.org/rfcb/1138 ; DOI : https://doi.org/ $10.4000 /$ rfcb. 1138

\section{(c) (†) $\odot$}

Revue française de civilisation britannique est mis à disposition selon les termes de la licence Creative Commons Attribution - Pas d'Utilisation Commerciale - Pas de Modification 4.0 International. 


\title{
Trade unionists and the Labour Party in Britain: the bedrock of success
}

\author{
Chris WRIGLEY \\ University of Nottingham
}

\begin{abstract}
The trade union-Labour Party link has been termed 'The Contentious Alliance' by the author Lewis Minkin. ${ }^{1}$ It was contentious with the pre-1914 socialists and the post-1994 New Labour Blairites as well as with Labour's political opponents, the Conservative and Liberal parties. Yet, for the Labour Party the trade unions provided a solid bedrock of support and an ideological solidity in hard times, as in the face of National Labour in the 1930s and the break-away of the Social Democrat Party (SDP) in the 1980s. The trade unions were a reality that the British socialists could not ignore. British trade unionism was the oldest in Europe, stretching back through the eighteenth century to very early printers' societies in the late seventeenth century. By the late nineteenth century trade unionism was strong among skilled workers, was established in some counties with mining and, with the 'New Unionism' of 1888-90, trade unionism flourished among the unskilled (before weakening substantially by the mid-1890s). In contrast with Germany where the SPD was huge before trade unionism expanded rapidly in the later 1890s, in Britain the socialists were small in number and fragmented, dwarfed by the trade unions [see Table 1]. The Marxist Social Democrat Federation (SDF) is credited with some 689 paid-up members in 1886-7, but it seems to have had more than that, albeit ones who were unable or failed to pay. The breakaway Socialist League, with William Morris (1834-96) as its charismatic leader, was smaller still. Before 1897 the SDF leadership which drew on Robert Owen (1771-1858) and the more socialist of the Chartist leaders as well as on Marx, was very critical of trade unionism which was deemed to be 'a recognition of capitalism and the right to exploit', though there were strong advocates of trade unionism within the SDF. Morris was also for long highly critical of trade unionism but he campaigned in the mining areas of the North East, becoming a late convert to the need to gain trade union support. ${ }^{2}$
\end{abstract}

\footnotetext{
${ }^{1}$ Lewis MINKIN, The Contentious Alliance: Trade Unions and the Labour Party, Edinburgh: Edinburgh University Press, 1991.

${ }^{2}$ Martin CRICK, The History of the Social Democratic Federation, Keele: Ryburn Publishing, Keele University Press, 1994, pp. 68 and 77. E.P. THOMPSON, William Morris: From Romantic To Revolutionary, London: Lawrence and Wishart, 1955, pp. 517-24.
} 
Table 1

(a) Trade Union Membership: UK and Germany 1896-1929

\begin{tabular}{|c|c|c|c|c|}
\hline & $\begin{array}{c}\text { UK membership } \\
(000 \mathrm{~s})\end{array}$ & Density (\%) & $\begin{array}{c}\text { Germany membership } \\
(000 \mathrm{~s})\end{array}$ & Density (\%) \\
\hline 1896 & 1,608 & 10.5 & 409.1 & 3.0 \\
\hline 1913 & 4,135 & 23.1 & $3,023.1$ & 16.4 \\
\hline 1920 & 8,348 & 45.2 & $9,192.9$ & 45.2 \\
\hline 1929 & 4,858 & 25.7 & $5,748.1$ & 26.3 \\
\hline
\end{tabular}

Notes: The German figures exclude the salaried employee associations. Density is the proportion of members out of those legally eligible to be members.

(b) Labour Party and SPD Membership

\begin{tabular}{|c|c|c|c|}
\hline & Labour & (\% Socialist Societies) & SPD \\
\hline 1907 & $1,072,413$ & $(2.08)$ & 530,000 \\
\hline 1914 & $1,612,147$ & $(2.06)$ & $1,085,905$ \\
\hline 1920 & $4,359,807$ & $(1.03)$ & $1,180,000$ \\
\hline 1929 & $2,330,847$ & $(1.14)$ & $*$ \\
\hline
\end{tabular}

Sources: G.S. Bain and R. Price, Profiles Of Union Growth (Oxford, Blackwell, 1980), pp.37 and 133. Henry Pelling and Alastair J. Reid, A Short History of the Labour Party, $11^{\text {th }}$ edition (London, Macmillan, 1996), p.197. W.L. Guttman, The German Social Democratic Party 1875-1933 (London, Allen and Unwin, 1981), p.153.

The Independent Labour Party (ILP), founded in Bradford in 1893 and the largest of the late nineteenth century socialist bodies (with 10,720 paid-up members in 1894-5), was much closer to trade unionism than the SDF. ${ }^{3}$ Nevertheless, a few of its leading figures, most notably Philip Snowden (1894-1937), who was to be Chancellor of the Exchequer in the first two Labour governments (1924 and 192931), were famously often hostile to the trade unions. James Ramsay MacDonald (1866-1937), chairman of the Parliamentary Labour Party (in effect leader) 1911-14, Leader of the Labour Party 1922-31 and Labour Prime Minister (1924 and 1929-31) was also far from enthusiastic about trade unionism. This was in contrast to other major early Labour Party figures who were (or had been) trade unionists, such as James Keir Hardie (1856-1915), David Shackleton (1863-1938) and Arthur Henderson (1863-1935). ${ }^{4}$

In the second half of the nineteenth century most British trade union leaders were Liberal Party supporters while most trade unionists voted Liberal, but in

3 David HOWELL, British Workers and the Independent Labour Party 1888-1906, Manchester: Manchester University Press, 1983, p. 328.

${ }^{4}$ Keith LAYBOURN, Philip Snowden, Aldershot: Temple Smith, 1988, pp. 52-3. David MARQUAND, Ramsay MacDonald, London: Jonathan Cape, 1977. Kenneth O. MORGAN, Keir Hardie: Radical and Socialist, London: Weidenfeld and Nicolson, 1975. Ross MARTIN, The Lancashire Giant: David Shackleton, Labour Leader and Civil Servant, Liverpool: University of Liverpool Press, 2000. Chris WRIGLEY, Arthur Henderson, Cardiff: University of Wales Press, 1990. 
Lancashire, Birmingham and elsewhere many voted Conservative. In the mid to late 1880s a younger generation of trade union leaders - such as James Keir Hardie and Robert Smillie (1857-1940), both Scottish coal-miners, Tom Mann (1856-1941), and John Burns (1858-1943), both engineers, and Ben Tillett (1860-1946), a general labourer - were socialists and were involved in organising the unskilled workers in such sectors as gasworks, docks and shipping as well as in rebuilding coal mining trade unionism, which had crumbled in some parts of Britain. Both the older skilled trade unions and the large, enthusiastic new unions provided the mass support for the huge May Day demonstrations of the early 1890s, with 250-300,000 turning out in London alone in 1890-93. ${ }^{5}$

British trade unionism, which had been more akin to the less party-political trade unionism of the USA than the political trade unionism of continental Europe, moved decisively towards independent labour representation in Parliament at the end of the 1890s in the face of employers' offensives against trade unionism and a series of legal decisions, culminating in the Taff Vale judgement 1902, which undercut what the unions believed to be their rights, as established in the trade union legislation in 1871-75. In 1899 the Trades Union Congress (TUC, established in 1868 as an annual conference of trade unions but with an executive which could take action in line with the conference's decisions) voted 'to invite the co-operation of all Co-operative, Socialistic, Trade Unions and other working class organisations' in holding a conference 'to devise ways and means for securing the return of an increased number of Labour members to the next Parliament'.

The Labour Representation Committee (LRC), formed in 1900, following the TUC's 1899 resolution, went wider than trade unions affiliated to the TUC. The inaugural conference held in Faringdon Street, London, on 27 and 28 February 1900, was attended by representatives of 66 trade unions, the Midland Counties Trades Federation, and three socialist societies (the ILP, the SDF and the Fabian Society, which had been founded in 1884 and for 1899 gave its membership as 861). The SDF affiliated but withdrew after one year, the co-operative movement, which in most areas remained Liberal until the First World War, did not affiliate en masse but some co-operative societies did between 1906 and 1917 and from 1927, but many trade unions and the ILP and Fabian Society joined and stayed. ${ }^{6}$ More than that, the Taff Vale Judgement of 1901, which awarded huge damages and legal costs against the Amalgamated Society of Railway Servants (ASRS) and thereby set a legal precedent which undercut unions' abilities to conduct strikes, encouraged most major trade unions to affiliate to the LRC to secure legislation to undo this legal verdict. By 1904 all the major unions had affiliated to the TUC except most of the coal miners, who did so in 1909.

${ }^{5}$ Chris WRIGLEY, 'Great Britain' in Andrea Panaccione, The Memory of May, Venice: Marsitio Editori, 1989, pp. 83-108, and 'The Memory of May' in History Today, June 1990, pp. 35-41. Gita DENECKERE, Marie-Louise GOERGEN, Inge MARSSOLEK, Danielle TARTAKOWSKY, 'Premiers mai' in Jean-Louise Robert, Friedhelm Boll and Antoine Prost (eds), Les Invention Des Syndicalisme, Paris : Sorbonne, 1997, pp. 199-217.

${ }^{6}$ B.C. ROBERTS, The Trade Union Congress: 1868-1921, London: Allen and Unwin, 1958.

Chris WRIGLEY, 'The TUC 1868-1968', in TUC, Working For Your Future: The TUC 1868-1993, London: TUC, 1993, pp. 7-29. 
The LRC won two seats in the 1900 general election and three further seats in by-elections. In the 1906 general election 29 of its 50 candidates were elected, with the numbers of successful candidates going up in the January 1910 (40 of 78) and the December 1910 (40 of 56) after the mining unions had affiliated. The MPs elected in the general elections of 1906, January 1910 and December 1910 were overwhelmingly working class, with 23 of all 29 of 1906 being working class and 23 of these being manual worker trade unionists. ${ }^{7}$

Yet, the impact of the ILP was disproportionate in the pre-1914 Parliamentary Labour Party to its membership, which ran at around 2 per cent of the trade union affiliates to the Labour Party (see Table 1B). Although seven of the 29 MPs were ILP sponsored, many more were also ILP members as well as trade unionists. This was notably so in the case of J.R. Clynes (1869-1949), who was to be Food Controller in 1918 in David Lloyd George's wartime coalition government. In the final vote for the first chairman of the Parliamentary Labour Party Keir Hardie beat David Shackleton by one vote. The post rotated and after Hardie, 1906-8, the next two chairmen were trade unionists, Arthur Henderson, 1909-10 and George Barnes (1859-1940), 1910-11, before James Ramsay MacDonald, 1911-14. While some trade unionist MPs were also ILP members, others were anti-socialist. In the case of Arthur Henderson, when, as Secretary of the Labour Party (1912-34), he was the UK link with the Second International and it was felt to be diplomatic for him to be a member of a socialist society, it was notable that in 1912 he joined not the ILP but the very moderate Fabian Society.

The early Labour leaders took care to acknowledge their dependence on the trade unions. Ramsay MacDonald, when delivering fraternal greetings to the TUC in 1904 stated: 'The Labour Representation committee is neither sister nor brother to the Congress, but its child'. ${ }^{8}$ The trade unions very largely funded the Labour Party. In the 1906 and two 1910 general elections there were 186 candidates, of whom 137 were sponsored by trade unions. In 1906 the unions funded 79 per cent and in the two 1910 general elections 90 per cent of total expenditure (with the Miners' Federation of Great Britain affiliated from 1909). In 1910 the Miners' Federation paid an average of $£ 1,225$ per candidate for its 49 candidates, the other unions paid an average of $£ 696$ per candidate for their 54 candidates and the socialist societies paid an average of $£ 467$ for each of their 31 candidates. The total political expenditure of the trade unions, including local as well as national elections, during 1906 to 1910 , was in excess of $£ 150,000$. $^{9}$

That such large amounts of trade union money were going to Labour Party candidates outraged some trade unionists who supported either the Liberals or the Conservatives. Walter Osborne, a railwayman who had once been a member of the SDF, became a campaigner for trade unions which (as he put it in his book Sane Trade Unionism) bargained 'merely for the rightful division of the profits as between

${ }^{7}$ L. MINKIN, Contentious Alliance, p. 13.

${ }^{8}$ H.A. CLEGG, A. FOX and A.F. THOMPSON, A History of British Trade Unions Since 1889, Vol. 1, Oxford: Oxford University Press, 1964, p. 380.

9 Michael PINTO-DUSCHINSKY, British Political Finance 1830-1980, Washington: American Enterprise Institute for Public Policy Research, 1981, pp. 62-4. 
the two partners - capital and labour'. He took the view that 'there can be no liberty apart from private property. Property and the means of existence in many hands guarantee independence and freedom'. His attempts to set up a Trade Union Political Freedom League and a socialist-free British Labour Party did not get far. ${ }^{10}$

However, Osborne succeeded in gaining a verdict at the Court of Appeal, and upheld by the Law Lords, against his union the Amalgamated Society of Railway Servants (ASRS) over its levying money for political purposes. He had failed in the lower court, as had a group of Conservative South Wales miners in 1907, who objected to union funds supporting Liberal candidates. The Osborne Judgement, 1909, rendered many trade union activities illegal, including financing newspapers, and it even made support for trades councils and the TUC questionable. However, trade unions set up voluntary funds (which accumulated far smaller sums) and the unions pressed for changes in the law. This came with the Trade Union Act 1913, which required trade unions to hold ballots to establish political funds and made provision for members to contract out of paying the political levy. ${ }^{11}$ While some trade unions had large minority votes against establishing a political levy - with the minority against being 88.0 per cent of the Yes vote in the Association of Carpenters and Joiners, 77.3 per cent in the Amalgamated Weavers Association and 74.5 per cent of the Miners' Federation of Great Britain - all the large unions did vote in favour, with the total vote of unions registered with the Chief Registrar of Friendly Societies breaking down to 70.4 per cent in favour and 29.6 per cent against. ${ }^{12}$

A feature of the period 1905-14 was the way that the older political parties sought to gain trade unionist political support and manoeuvred to block others benefiting from trade union funds. The Conservative Party throughout the twentieth century repeatedly sought to create a credible Conservative trade union body. In the period after the 1906 general election, when the Conservatives lost many seats in working class areas of Lancashire, they made particular efforts to organise sympathetic workers. The Labour MP J.R. Clynes, who represented a Manchester seat, commented in the House of Commons in 1912: 'Conservative agents are known to be endeavouring to organise and establish rival trade unions constitutional trade unions, non-political trade unions - and all you have to do to be a non-political trade unionist is to be a Tory, and generally to associate yourself with the party of that name'. Andrew Bonar Law (1858-1923), soon to be the Conservative Party leader, wrote in October 1910 that he wanted the Osborne Judgement upheld but favoured the payment of Members of Parliament. For he believed 'that the members of Trade Unions would not see the fun of subscribing for political purposes, and that therefore the political influence of the Trade Unions would be destroyed'. ${ }^{\prime \prime}$

${ }^{10}$ W.V. OSBORNE, Sane Trade Unionism, London: Collins, 1913. Chris WRIGLEY, 'Labour and the Trade Unions' in K.D. Brown (ed.), The First Labour Party 1906-1914, London: Croom Helm, 1985, pp. 129-57.

${ }^{11}$ W.B. GWYN, Democracy and the Cost of Politics, London: Athlone Press, 1962, pp. 178205.

${ }^{12}$ Report of the Chief Registrar of Friendly Societies for the Year 1912, London: HMSO, 1914, pp. 91-2.

${ }^{13}$ WRIGLEY, 'Labour and the Trade Unions', pp. 138-41. 
The political influence of the trade unions was enhanced in the industrially turbulent pre First World War years and even more so in the war and the postwar boom of 1919-20. Table 2 provides details of the considerable rise in trade union membership 1911-20. Over half the male labour force was in trade unions in 1919 and 1920, densities not achieved again until after the Second World War in 1946, while the 1920 female density was only surpassed from 1942. Trade union membership went up in the war years even though some 5.9 million men went into the Armed Forces. Although trade union affiliation fees to the Labour Party were lowered, the sheer greater number of trade unionists resulted in the Labour Party having bigger resources for fighting postwar elections. Trade union financial strength generally was greater not only because of increased income but also as there were reductions in some costs (few being unemployed and with strikes illegal, most strikes were unofficial).

Table 2

UK Trade Union Membership 1910-21 (in thousands)

\begin{tabular}{|l|l|l|l|l|l|l|}
\hline & \multicolumn{2}{|c|}{ Male } & \multicolumn{2}{c|}{ Female } & \multicolumn{2}{c|}{ Total } \\
\hline & Membership & Density & Membership & Density & Membership & Density \\
\hline 1910 & 2287 & 18.6 & 278 & 5.3 & 2564 & 14.6 \\
\hline 1911 & 2804 & 22.6 & 335 & 6.3 & 3139 & 17.7 \\
\hline 1912 & 3026 & 24.3 & 390 & 7.2 & 3416 & 19.1 \\
\hline 1913 & 3702 & 29.6 & 433 & 8.0 & 4135 & 23.1 \\
\hline 1914 & 3708 & 29.5 & 437 & 8.0 & 4145 & 23.0 \\
\hline 1915 & 3868 & 30.7 & 491 & 9.0 & 4359 & 24.1 \\
\hline 1916 & 4018 & 31.8 & 626 & 11.4 & 4644 & 25.6 \\
\hline 1917 & 4621 & 36.4 & 878 & 15.9 & 5499 & 30.2 \\
\hline 1918 & 5324 & 41.8 & 1209 & 21.7 & 6533 & 35.7 \\
\hline 1919 & 6600 & 51.6 & 1326 & 23.7 & 7926 & 43.1 \\
\hline 1920 & 7006 & 54.5 & 1342 & 23.9 & 8348 & 45.2 \\
\hline 1921 & 5628 & 43.6 & 1005 & 17.8 & 6633 & 35.8 \\
\hline
\end{tabular}

Source: Bain and Price, Profiles of Union Growth, p.37

The huge wartime demand for manpower put labour in a strong position in the labour market in Britain as in other belligerent nations. The British government came to a voluntary agreement to suspend strikes and achieve labour flexibility with some major trade unions at the Treasury conference in February 1915. These changes became statutory requirements with the Munitions of War Act, 1915. As the state took control of more and more of British industry and settled wage rates nationally, the TUC and the key trade unions were increasingly consulted by government and brought into wartime committees. Similarly, when the first wartime coalition government was formed by H.H. Asquith (1852-1928), Arthur Henderson entered the Cabinet on behalf of the Labour Party. When Asquith was succeeded as Prime Minister by David Lloyd George (1863-1945) in 1916, Henderson became a member of the small War Cabinet (and on resigning in August 1917, he was succeeded by G.N. Barnes, another prominent former trade union leader). So during the First World War the trade unions had moved from the margins of government, often making their points by presenting petitions, to being consulted at the highest 
levels of government. The Labour Party had emerged from being dependent on an electoral pact with the Liberal Party.

While the British trade unions had been overwhelmingly moderate before the First World War, there had been some notably socialist trade unionists, ranging from Tom Mann, Ben Tillett, Will Thorne and other leading 'New Unionists' to militant miners in South Wales. The pressures of the First World War, with severe restrictions on labour yet with much profiteering in industry and retailing, led to the radicalisation of many workers. In metal working centres such as Sheffield and Glasgow, as in Berlin, St Petersburg, Milan and Turin, militant left wing trade unionism emerged.

Militant engineering workers provided many of the early leaders of the Communist Party of Great Britain (CPGB), with many others coming from coalmining or the railways. Tom Mann, who was the best known trade unionist in the early period of the CPGB, wrote in a pamphlet praising Soviet Russia:

Let me suppose the reader is an unemployed member of the Amalgamated Engineering Union; has exhausted state unemployed benefit, is now receiving only a few shillings a week from the union, family life rapidly deteriorating... confronted with the employers' present demand that those in work shall be subjected to 'another 121/2 per cent reduction in wages. Are you one who still fails to see the necessity for a change of system from Dictatorship of the Bourgeoisie to Dictatorship of the Proletariat? ${ }^{14}$

In Britain, however, there was no major split in the trade union movement, although the CPGB had some, although limited, success with a minority movement in the trade unions and with the National Unemployed Workers' Movement (which gained some support beyond the CPGB). The great majority of British trade unionists remained moderate, though after 1918 more were likely to vote Labour than Liberal.

The 1918 general election was fought in the euphoria of victory, with Lloyd George and his coalition Liberal and Conservative supporters winning a landslide victory. Most of the Labour Party leaders lost their seats. Yet the solid bedrock of trade union votes in some constituencies ensured 57 MPs were elected, of whom 25 were miners and 24 sponsored by other trade unions. The financial strength of the miners was displayed in Durham, where the miners funded 10 sub agents, 39 polling agents and 97 clerks, and in six mining area seats in County Durham, where they funded 66 sub agents, 68 polling agents and 65 clerks. ${ }^{15}$

During and after the First World War the Labour Party widened its appeal

${ }^{14}$ Tom MANN, Russia In 1921, London: British Bureau, Red International of Labour Unions, n.d. [1921]), p. 18. Tom MANN, 'The Case for the Engineers' in Philip Snowden and others, What We Want And Why, London: Collins, 1922, pp. 90-133.

${ }^{15}$ Duncan TANNER, Political Change and the Labour Party 1900-1918, Cambridge: Cambridge University Press 1990, p. 465. 
beyond male trade unionists. Before 1914 the party had supported votes for women and it had promoted several inner city issues, including providing breakfasts at schools for needy children and providing better housing, as well as campaigning for pensions and on behalf of the unemployed. After the war, Labour continued to speak up for equality. In 1919 there was a breakaway trade union from the National Union of Teachers, the National Association of Schoolmasters, which represented a revolt of male teachers over pressure for equal pay for their female colleagues. Henderson, writing in a Labour educational journal in March 1920 was firmly in support of equality, writing: 'The present disparities in the remuneration of men and women teachers cannot be defended on the grounds of justice or expediency'. ${ }^{16}$ During the war the Labour Party won much support by taking up issues such as food shortages and insufficient allowances for soldiers' wives and children or widows. Also the Labour Party's constitution, organisation and policies were overhauled in 1917-18 under the direction of Henderson, with the intention of turning the party into a broad based party competing for office. Yet, it was in the later 1920s, as Mike Savage, a historical sociologist, has argued, that Labour politics in many areas became based on 'a new network of popularly controlled neighbourhood institutions', with women's organisations being especially important. ${ }^{17}$

Nevertheless, the trade unions remained at the centre of Labour politics. Representatives of the TUC and the General Federation of Trade Unions (GFTU) joined with the Labour Party's national executive committee in the Joint Board from 1906 to $1921 .{ }^{18}$ This had discussed amendments to such measures as the Trades Disputes Bill in 1906 and the National Insurance Bill in 1911. Henderson, who chaired the Joint Board from 1910, used it to steer the trade unions the way the Labour Party wished to go. It was replaced in 1921 with the National Joint Council (in 1934 renamed the National Council of Labour), with equal numbers of representatives from the newly formed General Council of the TUC, the Labour Party's national executive committee and the Parliamentary Labour Party. ${ }^{19}$

Labour in office in 1924 and 1929-31 annoyed the trade union leadership by insufficiently consulting the National Joint Council on policies. The National Joint Council met only twice in 1924 and, as Vic Allen has written, it transacted little and relatively unimportant business'. Ramsay MacDonald, Prime Minister, avoided consulting the TUC general secretary. Overall, the trade union leadership believed the first Labour government failed to respond to trade union concerns, whether over unemployment or industrial grievances. After the fall of the government, Ernest Bevin (1881-1951), the powerful general secretary of the Transport and General Workers' Union (TGWU) wanted MacDonald replaced by

\footnotetext{
${ }^{16}$ Arthur HENDERSON, 'Labour and Education', The New Highway, 1, 31 March 1920, p. 1. ${ }^{17}$ Mike SAVAGE, The Dynamics of Working Class Politics: The Labour Movement in Preston 1880-1940, Cambridge: Cambridge University Press, 1987, pp. 195-8.

${ }^{18}$ G.D.H. COLE, A History of the Labour Party From 1914, London: Routledge and Kegan Paul, 1969, p. 265.

${ }^{19}$ Chris WRIGLEY, Arthur Henderson, Cardiff: University of Wales Press, 1990, pp. 51, 61 and 64-5. Ross MCKIBBIN, The Evolution of the Labour Party 1910-1924, Oxford: Oxford University Press, 1974, pp. 211-3.
} 
Henderson as Leader of the Labour Party. ${ }^{20}$

MacDonald's distancing himself from the trade union leadership was part of his concern to make the Labour Party a national party, not a party largely restricted in its appeal to one class. Such concerns were heightened in the General Strike, May 1926, when the TUC backed the coal miners in resisting cuts in wages and other working conditions. MacDonald had long argued against general strikes and believed the miners' demands were unrealistic. In his diary on 2 May 1926 he commented: 'The election of this fool [the militant Arthur Cook (1883-1931)] as miners' secretary looks as though it would be the most calamitous thing that has ever happened to the TU movement. The chief criminal, however, is the Government' ${ }^{21}$ This situation was echoed in the 1984-5 mining strike when the then Labour Party leader, Neil Kinnock (1942- ), while supporting the miners, made clear his lack of enthusiasm for the union president, Arthur Scargill (1938- ).

From the First World War until the General Strike the Labour Party's opponents liked to claim there was a revolutionary threat, with the trade unionists as gullible people who could be exploited by the ruthless. Earlier, the young Winston Churchill in his only novel, Savrola (1900), had mixed together upper class British fears of bomb-throwing anarchists with concern over the rise in Germany of the SPD. After the Bolshevik revolution in Russia in 1917 right-wing authors such as John Buchan (1875-1940), who wrote some of his novels when Director of the Department of Information 1917-8, and 'Sapper' (Cyril NcNeile 1888-1937) depicted sinister figures manipulating trade unionists, leading them away from 'patriotic' views into socialism. Conservative politicians similarly warned of dangerous forces at work behind the moderate trade union figures. Lloyd George, the Liberal Prime Minister of a coalition government, observed in 1920 that:

the great danger of a Labour government was that they would allow themselves to be rushed and would lose control... If Henderson and his friends were in authority and there was a strike, say, in Manchester, they would not be prepared to use force to preserve law and order. They would send a man down to talk to the crowd. And they would share Kerensky's fate. ${ }^{22}$

Ramsay MacDonald and the other Labour Party leaders had been happy during the first Labour Government of 1924 to demonstrate their responsibleness in office. The second Labour Government, 1929-31, was also moderate. The Liberal leader, Lloyd George, often felt frustrated at the inability of MacDonald (Prime Minister), Philip Snowden (Chancellor of the Exchequer) and their colleagues to break away from fiscal orthodoxies and to undertake imaginative remedies to growing unemployment. These failings also angered leading trade unionists, most notably Ernest Bevin. The Parliamentary Labour Party of 287 had 115 trade union

${ }^{20}$ Vic ALLEN, Trade Unions And The Government, London: Longmans, 1960, pp. 223-38. Alan BULLOCK, The Life And Times Of Ernest Bevin: Trade Union Leader, 1881-1940, London: Heinemann, 1960, pp. 258-9.

${ }^{21}$ David MARQUAND, Ramsay MacDonald, London: Cape, 1977, pp. 435-6.

${ }^{22}$ Lord Riddell's diary, 10 January 1920. Riddell Papers, British Library, Add. Ms. 62985, f. 7-8. 
sponsored members. At 40 per cent, this was lower than ever before (there being 53 and 58 per cent of the Labour MPs sponsored by trade unions after the previous general elections of 1923 and 1924). MacDonald took no more notice of the trade unions than he had in $1924 .^{23}$

However, the balance of power tilted strongly towards Bevin and the trade unions after the departure of Ramsay MacDonald to be Prime Minister of a Conservative dominated government in 1931, followed that autumn by a general election in which MacDonald and Snowden denounced their former colleagues and the number of Labour MPs fell from 289 to 46 (plus five ILP candidates who did not seek Labour Party endorsement and one Independent). Bevin and Walter Citrine (1887-1983), General Secretary of the TUC 1926-46, resurrected the National Joint Council and the trade union leaders had an input into such crucial but contentious issues of the 1930s as defence and foreign policy. Yet, as Lewis Minkin has emphasised, the two sides kept to themselves the final say over their distinctive political and industrial roles. ${ }^{24}$

From 1929 Ernest Bevin's thinking on economic issues became very influential in the labour movement. With the economist J.M. Keynes (1883-1946), he served on the Macmillan Committee on Finance and Industry, 1930-1, and argued for devaluation of the pound. He also served with Keynes on the Economic Advisory Committee set up in 1930 to advise the government. On the TUC's economic committee he accepted the case for tariffs. In 1931-2 he chaired the Society for Socialist Inquiry and Propaganda, a body which later would have been termed a think-tank. With Citrine in 1935-7 he moved the Labour Party away from its near pacifist policies to demanding rearmament. ${ }^{25}$

Table 3: UK Trade Union Membership and the Labour Party's vote in general elections, 1931-9

Trade Unions (thousands)

\begin{tabular}{|r|r|r|r|r|r|r|r|}
\hline & $\begin{array}{l}\text { Male } \\
\text { member- } \\
\text { ship }\end{array}$ & $\begin{array}{l}\text { Density } \\
(\%)\end{array}$ & $\begin{array}{l}\text { Female } \\
\text { member- } \\
\text { ship }\end{array}$ & $\begin{array}{l}\text { Density } \\
(\%)\end{array}$ & $\begin{array}{l}\text { Total } \\
\text { membership }\end{array}$ & $\begin{array}{l}\text { Density } \\
(\%)\end{array}$ & $\begin{array}{l}\text { Labour } \\
\text { Party vote }\end{array}$ \\
\hline 1931 & 3859 & 29.1 & 765 & 12.8 & 4624 & 24 & $6,62,561$ \\
\hline 1933 & 3661 & 27.4 & 731 & 12.0 & 4392 & 22.6 & - \\
\hline 1935 & 4106 & 30.6 & 736 & 12.4 & 4590 & 23.5 & $8,325,491$ \\
\hline 1939 & 5288 & 38.9 & 1010 & 16.0 & 6298 & 31.6 & - \\
\hline
\end{tabular}

Source: Bain and Price, Profiles of Union Growth, p. 37. Pelling and Reid, A Short History of the Labour Party, p.200.

${ }^{23}$ ALLEN, Trade Unions And The Government, pp. 239-49.

${ }^{24}$ MINKIN, The Contentious Alliance, pp. 30-1.

${ }^{25}$ BULLOCK, The Life and Times of Ernest Bevin, Vol. 1, pp. 417-518. Margaret COLE,

'The Society for Socialist Inquiry and Propaganda' in A. Briggs and J. Saville (eds), Essays in Labour History 1918-1939, London: Macmillan, 1977, pp. 190-203. Chris WRIGLEY, 'Bevin, Ernest (1881-1951)' in Oxford Dictionary of National Biography, Oxford: Oxford University Press, 2004. 
Trade union membership, which had fallen since 1921, and Labour Party support both began to recover during the 1930s. Table 3 indicates UK trade union membership and the votes given to the Labour Party in the 1930s. In the 1935 general election 79 of the 154 elected Labour candidates were trade unionists. Of these 34 were sponsored by the Miners' Federation of Great Britain, a much larger number than the second largest group, seven, sponsored by the Transport and General Workers' Union. ${ }^{26}$

Labour returned to office in Winston Churchill's wartime coalition government, 1940-5. Ernest Bevin, the most powerful trade union leader of the interwar years, was Minister of Labour and National Service and from September 1940 until the end of the war in Europe a member of Churchill's small war cabinet. Churchill wrote of Bevin that he had the whole man-power of the nation to manage and animate. All the workers in the munitions factories were ready to take his direction ${ }^{, 27}$ The trade union movement emerged from the Second World War strong and widely respected for its part in the war effort. At the 1947 Conservative Party conference Churchill stated: 'The trade unions are a long-established and essential part of our national life... we take our stand by these pillars of our British Society as it has gradually developed and evolved itself, of the right of individual labouring men to adjust their wages and conditions by collective bargaining, including the right to strike...'. At the 1950 Conservative Party conference he urged 'every Tory craftsman or wage earner' to be an active member of a trade union. ${ }^{28}$ This was a long way from Conservative Party attitudes earlier, or later under Margaret Thatcher.

There was greater harmony between the third (and first majority) Labour government under Clement Attlee (1883-1967), 1945-51. In the 1945 general election 393 Labour candidates were elected, 31 per cent of whom were trade union sponsored. Again the largest group was the miners, 35 standing and 35 being elected, with the TGWU again second, which had 17 of its 18 candidates elected. Three railway unions (NUR, RAC and ASLEF) secured the election of 22 of their 23 candidates. Of the six trade union sponsored MPs in the cabinet, Ernest Bevin was Foreign Secretary, Aneurin Bevan (1897-1960) was Minister of Health and George Isaacs (1883-1979), who had been secretary of the National Society of Operative Printers and Assistants (NATSOPA), 1909-49, and chairman of the TUC, 1945, was Minister of Labour. Attlee was more eager than MacDonald that his ministers should consult the TUC and individual unions wherever possible. The government repealed the Trade Disputes and Trade Unions Act 1927, hostile legislation which had followed the General Strike, 1926, and it also pleased the trade union movement with its broad programme of nationalization (but not with the amount of trade union participation in management) and the establishment of the Welfare State. ${ }^{29}$

${ }^{26}$ COLE, A History of the Labour Party from 1914, pp. 312-3.

${ }^{27}$ Winston S. CHURCHILL, The Second World War, Vol. 2, London: Cassell, 1949, p. 287.

${ }^{28}$ Chris WRIGLEY, 'Churchill and the Trade Unions', Transactions of the Royal Historical Society, $6^{\text {th }}$ Series, 11,2001 , pp. 273-93 (quotations at p. 291).

${ }^{29}$ COLE, A History of the Labour Party from 1914, p. 441. V.L. ALLEN, Trade Unions and the Government, pp. 267-80. 
The essential feature of the Labour Party-trade union relationship in 194551 was the support the trade union movement gave what it saw as its government in the massive task of reconstruction - both physical and financial - after the Second World War. The TUC backed the governments' voluntary incomes policy from 1948 until 1950 (when the 1949 devaluation added to other inflationary pressures to make severe restraint on wage rises unrealistic). In this period trade union and widespread public support made this incomes policy more effective than those of 1960-74. ${ }^{30}$

So what went wrong in British politics for the trade unions in the 1950s and after? The first issue was that fears of mass unemployment, as in the 1930s, were not realised. The prosperity in the international economy from about 1950 to 1973 avoided this. In Britain the avoidance of high unemployment was also facilitated by both Labour and Conservative governments following Keynesian counter-cyclical policies, trying to maintain a steady level of aggregate demand in the economy. The period 1950 to the early 1960s saw low unemployment and buoyant demand for labour. As a result the trade unions were in a strong position to press wage and other demands. In the 1950s inflation, not unemployment, became the worry of the Conservative governments of 1951-64 and the trade unions were deemed to be a major cause of rising costs in British industry. The issue of rising prices was examined in the 1956 government White Paper, The Economic Implications of Full Employment (Cmd 9725) which urged 'self-restraint in making wage claims and fixing profit margins'.

Related to concerns of trade union action raising prices were issues of relatively low productivity in British industry compared with other countries and strike levels. While British economic growth rates were good in comparison to the British past, including the classic Industrial Revolution period, they were poor compared to other Western industrialised countries, not least West Germany and Japan. Such concerns were not only aired by politicians but in the newspapers, in films such as I'm All Right Jack (1959) and on television. ${ }^{31}$ Alert to the likely adverse electoral implications of trade union unpopularity, Harold Wilson (191692), Prime Minister in the fourth Labour government, 1964-70, set up a Royal Commission on trade unions and employer organisations (1965-68) chaired by Lord Donovan. The Donovan Report supported the largely voluntary, as opposed to statutory, system of industrial relations, found that the problem of strikes was the high proportion of them being unofficial and found that the British level of strikes was at an intermediate level between those countries with a large number of disputes such as Italy, Ireland, Canada and the United States and those with relatively few, such as France and Japan. Nevertheless, much of the press and right wing politicians continued to argue that high levels of strikes were a peculiarly 'English disease'.

In early 1979 a series of strikes, many in the public sector, undermined confidence in the Labour government under James Callaghan (1912-2005), 1976-79. In previous industrial unrest, notably between the Conservative government of

${ }^{30}$ C. WRIGLEY (ed.), British Trade Unions 1945-1995, Manchester: Manchester University Press, 1997, pp. 34-42.

${ }^{31}$ Chris WRIGLEY, British Trade Unions Since 1933, Cambridge: Cambridge University Press, 2002, p. 49. 
Edward Heath (1916-2005), 1970-74, and the miners, the Labour Party had an advantage in being deemed to be able to work with the unions. The link also at first proved valuable in Harold Wilson's 1974-76 government, when the government and the unions made 'The Social Contract' whereby the unions supported incomes policy (which between 1975 and 1977 played a major part in cutting inflation from 24 to 8 per cent) and in return the government delivered social benefits (such as better pensions) and tax cuts. In the 'Winter of Discontent' of early 1979 the trade unions and strikes were a major liability for the Labour Party. In his diary on 16 January 1979, Bernard Donoughue (1934- ), Senior Policy Advisor to James Callaghan, noted of the strikes:

This is all creating a strong public reaction - against the unions, and against us. So this crisis is the worst for us in the past five years. The Tories have never been able to really hurt us. But our strongest card has been that we have seemed able best to deal with the unions. Now that card looks very weak.

On 19 January he noted Callaghan saying that he had been 'gravely politically damaged' in the past week. ${ }^{32}$

It was in this period that Margaret Thatcher dropped her caution on the issue of the trade unions and made 'taming the unions' a major feature of her politics. The Thatcher governments, 1979-90, were marked by a strong belief in the effectiveness of free market forces in making a strong economy, and part of this belief was a conviction that trade unions damaged the economy and resulted in worse levels of unemployment. The Labour-trade union link became a standard part of Conservative electioneering in the general elections of 1979, 1983 and 1992, with lessening favourable responses from the British electorate.

Conservative criticism of the Labour Party trade union link became less effective as the trade unions became weaker in the 1990s. UK trade union membership peaked at $13,289,000$ in 1979 but by 1995 had dropped to $8,089,000$. Trade union density fell from 53 per cent in 1979 to under 30 per cent by 1998 . It also became less effective because public opinion which had been hostile to the trade unions in the 1980 s became more positive to them when many felt the Conservatives had gone too far with hostile trade union legislation in the late 1980s and 1993 and with the closure of much of the coal industry. Furthermore, Conservative criticisms of the trade unions as a source of Labour Party funds became less damaging as the Conservative reliance on hedge funds and other finances appeared less admirable with the financial crisis of 2008.

The images of overmighty trade union barons, which had been built up by the popular press, have been undermined by the research of Lewis Minkin. While the trade unions continued to expect to be consulted by the Labour Party on industrial relations and employment issues, generally they did not exert pressure on

${ }^{32}$ Bernard DONOUGHUE, Downing Street Diary, Vol. 2, London: Cape, 2008, pp. 423 and 428. 
other policies as a price for their funds. Generally the trade union representatives on the Labour Party's National Executive Committee were forces for moderation and gave Labour's leaders loyal support. ${ }^{33}$ Nationally and at constituency level the trade unions have provided both finance and activists which have been a bedrock of support for the Labour Party.

\footnotetext{
${ }^{33}$ MINKIN, The Contentious Alliance, p. 626. Eric Shaw, 'Lewis Minkin and the party-union links' in John CALLAGHAN and Steven FIELDING (eds), Interpreting the Labour Party: Approaches to Labour Politics and History, Manchester: Manchester University Press, 2003, pp. 166-81.
} 